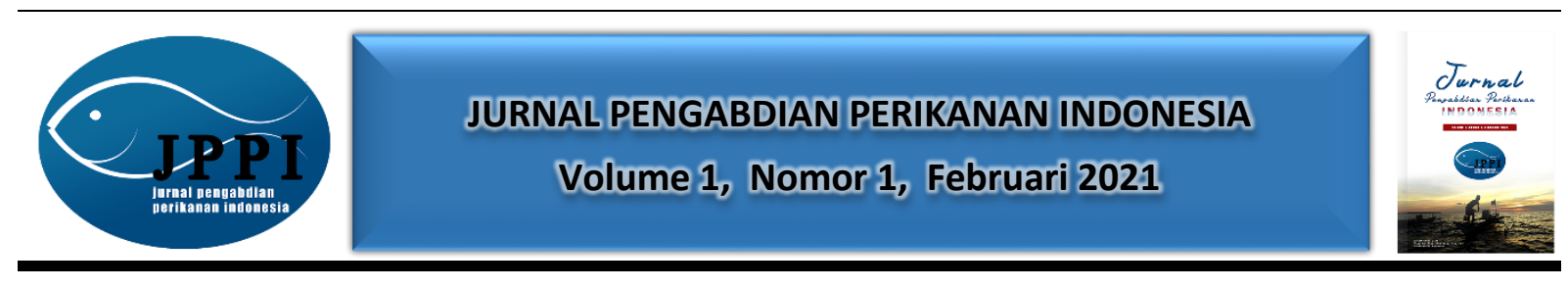

\begin{abstract}
SOSIALISASI PERSONAL HIGIENE PADA PEDAGANG IKAN PANGGANG DI KAWASAN WISATA KULINER LOANG BALOQ, KOTA MATARAM
\end{abstract}

\author{
Mutia Devi Ariyana, Nazaruddin, Sri Widyastuti, Baiq Rien Handayani, Moegiratul \\ Amaro
}

\begin{abstract}
Program Studi Ilmu dan Teknologi Pangan Universitas Mataram
\end{abstract}
Alamat korespondensi : mutiadevi0705@unram.ac.id

(Tanggal Submission: 3 Desember 2020, Tanggal Accepted : 2 Februari 2021)

\begin{abstract}
Keyword: Abstrak :
Ikan Loang Baloq saat ini menjadi sentra kuliner ikan panggang yang memiliki prospek Panggang, pengembangan untuk menunjang kepariwisataan daerah. Akan tetapi, perilaku dan kebiasaan Loang Baloq, masyarakat pedagang ikan panggang yang kurang memperhatikan aspek personal higiene Personal mengakibatkan kualitas ikan panggang yang dihasilkan terutama dari aspek mikrobiologis Higiene sangat jauh dari standar yang telah ditetapkan berdasarkan SNI. Permasalahan utama yang ditangani dalam kegiatan pengabdian ini yaitu minimnya pengetahuan para pedagang terkait prosedur personal higiene serta resiko dari segi keamanan pangan yang dapat ditimbulkan jika prosedur personal higiene tidak diterapkan dalam pengolahan ikan panggang. Solusi yang diberikan untuk meningkatkan kualitas dan keamanan pangan ikan panggang di Loang Baloq antara lain melalui edukasi terhadap pedagang sebagai pihak yang terlibat langsung dalam seluruh tahapan produksi terkait tujuan penerapan personal higiene, resiko tidak diterapkannya personal higiene, jenis perlengkapan personal higiene standar pengolah pangan beserta cara penggunaannya, serta prosedur personal higiene terutama cara mencuci tangan yang benar. Kegiatan dilakukan dengan metode ceramah, tanya jawab dan praktek langsung. Indikator capaian menunjukkan pedagang telah memahami apa yag dimaksud dengan personal higiene dan pentingnya penerapan personal higiene dalam pengolahan ikan panggang, pedagang telah mengetahui jenis perlengkapan standar personal higiene bagi pengolah pangan beserta cara penggunaannya dan pedangang juga sudah bisa mempraktekkan cara mencuci tangan yang benar.
\end{abstract}

Panduan Sitasi (APPA $7^{\text {th }}$ edition) :

Ariyani, M.D., Nazaruddin., Widyatuti, S., Handayani, B.R., \& Amaro, M. (2021). Sosialisasi Personal Higiene Pada Pedagang Ikan Panggang Di Kawasan Wisata Kuliner Loang Baloq, Kota Mataram. Jurnal Pengabdian Perikanan Indonesia, 1 (1), 21-28. http://doi.org/10.29303/jppi.v1i1.39

\title{
PENDAHULUAN
}

Aktivitas pariwisata di Nusa Tenggara Barat (NTB) khususnya Pulau Lombok menunjukkan peningkatan yang signifikan terutama setelah dinobatkan sebagai The World Best Halal Tourism Destination dan The World Best Halal Honeymoon Destination pada tahun 2015. Pada tahun 2019, NTB kembali dinobatkan sebagai destinasi wisata halal terbaik di Indonesia, versi Indonesia Muslim 
Travel Index (IMTI). Dengan pencapaian tersebut, Menteri Pariwisata Arif Yahya bahkan menargetkan jumlah wisatawan yang masuk ke NTB mencapai 4,5 juta orang pada tahun 2020 (iNews.id, 2019). Sebagai upaya untuk mencapai target tersebut, maka pengembangkan pariwisata baik dari segi promosi, fasilitas dan kualitas pelayanan terus dilakukan.

Pulau Lombok khususnya Kota Mataram memiliki ragam daya pikat yang terletak pada pada keunikan bentang alam dan budaya. Bentang alam terutama daerah pesisir pantai menjadi salah satu wisata unggulan. Adapun keunikan budaya tersaji dalam tradisi, adat, gaya hidup masyarakat dan kuliner. Perpaduan kedua aspek ini menjadikan Kota Mataram sebagai salah satu dari 11 Kawasan Strategis Pariwisata Daerah (Perda No.7 Tahun 2013 tentang KSPD) (Nugroho, 2019). Daya tarik wisata yang ditetapkan pada KSPD memiliki 8 ruang lingkup pengembangan berdasarkan Rencana Induk Pembangunan Kepariwisataan Daerah (RIPPARDA) tahun 2013-2028, salah satunya adalah daya tarik wisata Loang Baloq.

Loang Baloq berlokasi di sepanjang pesisir pantai Jalan Lingkar Selatan Tanjung Karang dan hanya berjarak $3 \mathrm{~km}$ dari pusat Kota Mataram. Daerah wisata ini sangat diminati khususnya oleh wisatawan lokal terutama akibat keberadaan sentra kuliner ikan panggang Terdapat sekitar 30 pedagang yang menjajakan ikan panggang di lapak-lapak yang berada dipinggir jalan sepanjang daerah Loang Balok. Jenis ikan panggang yang dijual dilokasi ini meliputi ikan kakap merah, baronang, tongkol, layang-layang, ekor kuning, kerapu dan pogot yang diperoleh dari pengepul asal Ampenan.

Usaha kuliner ikan panggang di Loang balok merupakan usaha skala kecil yang masih menggunakan peralatan serta teknik pemanggangan secara sederhana dengan bara api dari serabut kelapa. Pengolahan secara tradisional serta kesegaran bahan baku ikan panggang ini menghasilkan cita rasa khas yang menjadi daya tarik tersendiri bagi konsumen. Akan tetapi, perilaku dan kebiasaan masyarakat pedagang ikan panggang yang kurang memperhatikan aspek personal higiene justru menimbulkan citra yang kurang baik di mata masyarakat dan memuncul opini bahwa produk dari sentra ikan panggang ini kurang higienis.

Personal higiene menurut Depkes (2004) merupakan upaya kesehatan dengan cara memelihara dan melindungi kebersihan individu subyeknya. Personal higienemerupakan syarat mutlak bagi pengolahan pangan, sebab personal higieneberpengaruh langsung dan tidak langsung terhadap mutu dan keamanan pangan produk yang dihasilkan. Ditinjau dari perilaku dan kebiasaan masyarakat pedagang ikan panggang di Loang Balok terlihat bahwa pedagang kurang memahami mengenai personal higiene. Hal ini didukung oleh penelitian yang dilakukan oleh Ayuningtyas (2019) dimana pedagang ikan panggang di Loang Baloq belum menerapkan kebiasaan mencuci tangan yang baik dan benar sebelum melakukan pengolahan, kurang memperhatikan aspek kebersihan tubuh seperti kuku dan rambut serta pakaian yang digunakan saat pengolahan serta tidak terbiasa menggunakan perlengkapan sanitasi personal seperti sarung tangan, masker dan apron. Kondisi ini tentu saja akan memperbesar resiko kerusakan maupun keracunan makanan karena pada tubuh pedagang sebagai pihak yang kontak langsung dengan makanan terdapat berbagai jenis mikroba diantaranya adalah Eschericia coli, Aerobacter aerogenes, Streptococci, Enterococci, Salmonella kadang-kadang Staphylococci (Saksono,1986).

Potensi kerusakan dan keracunan akibat kontaminasi mikroba ini berpeluang terjadi pada ikan panggang di Loang Balok. Berdasarkan Ayuningtyas (2019) sebagian besar ikan panggang di Loang Balok tidak memenuhi kualitas mikroba berdasarkan SNI No.2725.1: 2009 (Badan Standarisasi Nasional, 2009) dimana total mikroba yang terdapat pada ikan panggang adalah $2.6 \times 10^{5}$ sampai $>2.5$ x $10^{5}$ sedangkan syarat mutu ikan asap SNI No.2725.1:2009 maksimal pertumbuhan mikroba sebesar 
$1,0 \times 10^{5}$, total kapang mencapai $2.2 \times 10^{3}$ sehingga berada diatas batas yang ditetapkan berdasarkan SNI yaitu sebesar $1,0 \times 10^{3}$, serta nilai total koliform $177,3 \mathrm{APM} / \mathrm{g}$ yang menunjukkan pertumbuhan koliform jauh diatas batas yang ditetapkan yaitu <3 APM/g.

Pedagang ikan panggang di Loang Baloq sebagai pihak yang terlibat langsung dalam seluruh tahapan produksi, mulai dari penyiapan bahan baku hingga pasca produksi merupakan unsur yang sangat penting dalam menentukan atau mengontrol faktor higiene produk yang dihasilkan. Rendahnya tingkat pendidikan, sosial dan ekonomi para pedagang mengakibatkan terbatasnya tingkat pengetahuan, sikap dan perilaku yang mendasari tentang personal higiene. Kondisi ini dapat mengarah pada terjadinya potensi bahaya baik secara fisik, kimia dan biologi yang dapat menyebabkan kontaminasi pada ikan panggang. Jika tidak diantisipasi maka kondisi ini akan menurunkan kualitas dan keamanan pangan ikan panggang yang dihasilkan. Oleh karena itu, perlu dilakukan suatu usaha untuk mensosialisasikan dan memberikan pengetahuan terkait dengan penerapan personal higiene dalam produksi ikan panggang kepada para penjual ikan di Jalan Lingkar Selatan Tanjung Karang (Loang Baloq), sehingga praktek personal higiene dapat dilaksanakan. Berdasarkan uraian di atas diharapkan terjadinya suatu kegiatan yang sinergis antara Perguruan Tinggi, Pemerintah Desa, dan Kelompok penjual ikan panggang melalui kegiatan "Sosialisasi Personal Higiene pada Pedagang Ikan Panggang Di Kawasan Wisata Kuliner Loang Baloq, Mataram".

\section{METODE KEGIATAN}

Kegiatan pengabdian pada masyarakat ini berupa penyuluhan khususnya sosialisasi personal higiene pada pengolahan ikan panggang. Pelaksanaan kegiatan utama mencakup beberapa tahapan seperti, (1) Penetapan sasaran pengabdian yang sesuai dengan profil yang telah ditentukan yaitu penjual ikan panggang di sekitar Jalan Lingkar Selatan Tanjung Karang (Loang Baloq) (2) Pengumpulan data awal berupa aspek mikrobiologis terkait personal higiene seperti uji kebersihan tangan pedagang, uji daya antiseptik sabun yang digunakan oleh pedagang dan uji kontaminasi dari rambut pedagang. Data hasil analisis aspek mikrobiologis terkait personal higienedigunakan sebagai materi penunjang pada kegiatan ini (3) Penyuluhan tentang aspek Personal higiene (3) diskusi yang dilakukan oleh tim dosen dan penjual ikan panggang tentang masalah dan kendala yang dihadapi masyarakat peserta dalam memproduksi ikan panggang serta saat pelaksanaan kegiatan berlangsung.

Kegiatan penyuluhan ini difokuskan pada kegiatan edukasi pedagang terkait penerapan personal higiene. Peserta penyuluhan dikhususkan bagi para pedagang ikan panggang yang berjualan di Loang Baloq. Metode pelatihan yang digunakan pada kegiatan ini fokus kepada kegiatan komunikasi, informasi dan edukasi produsen. Tahapan pemberian materi penyuluhan adalah sebagai berikut :

Tabel 1. Materi dan penyaji pada keigatan pengabdian kepada masyarakat

\begin{tabular}{|c|c|c|}
\hline No. & Materi & Penyaji \\
\hline 1. & $\begin{array}{l}\text { Sosialisasi akan makna dan pentingnya personal } \\
\text { higiene dalam proses pengolahan ikan panggang }\end{array}$ & Prof. Ir. Sri Widyastuti, M.App.Sc., Ph.D \\
\hline 2. & $\begin{array}{l}\text { Prosedur personal higiene dalam proses } \\
\text { pengolahan ikan panggang }\end{array}$ & Ir. Nazaruddin, MP \\
\hline 3. & $\begin{array}{l}\text { Dampak negatif dari pengolahan yang tidak sesuai } \\
\text { dengan prosedur sanitasi baik terhadap konsumen } \\
\text { maupun terhadap produk yang dihasilkan. }\end{array}$ & Baiq Rien Handayani, SP., M.Si.,Ph. D \\
\hline 4. & $\begin{array}{l}\text { Standar personal higiene pengolah pangan } \\
\text { (Teori dan praktik) }\end{array}$ & Mutia Devi Ariyana, S.Si., M.P. \\
\hline
\end{tabular}




\author{
Pentingnya mencuci tangan dan Cara Mencuci \\ 5. Tangan yang benar \\ (Teori dan Praktik) \\ Moegiratul Amaro, S.TP.,M.P.,M.Sc
}

Evalusi kegiatan penyuluhan ini dilakukan secara langsung pada saat kegiatan berlangsung. Tahap evaluasi dilakukan setelah penyampaian materi. Prosedur evaluasi meliputi kemampuan penguasaan materi dan tanggapan terhadap materi yang telah diberikan. Kedua kriteria tersebut diamati dengan keaktifan peserta dalam bertanya dan menanggapi materi yang diberikan. Selain itu, kehadiran peserta dalam setiap sesi penyuluhan juga menjadi parameter tingkat antusiasme peserta terhadap kegiatan penyuluhan yang dilakukan.

\title{
HASIL DAN PEMBAHASAN
}

Kegiatan pengabdian kepada masyarakat dengan tema "Sosialisasi Personal Higiene pada Pedagang Ikan Panggang di Kawasan Wisata Kuliner Loang Baloq, Mataram" dilaksanakan sebagai salah satu dukungan terhadap perbaikan kawasan wisata kuliner Loang Baloq sebagai salah satu Kawasan Strategis Pariwisata Daerah (KSPD). Sosialisasi personal higiene ini menjadi salah satu solusi yang dapat ditawarkan oleh pihak akademisi untuk meningkatkan kualitas dan keamanan pangan ikan panggang di daerah Loang Baloq yang saat ini masih berada di bawah standar yang dipersyaratkan berdasarkan SNI. Oleh karena itu, perbaikan personal higiene pedagang ikan panggang di kawasan Loang Baloq penting untuk dilakukan, terlebih lagi dalam era new normal seperti saat ini yang menuntut adanya peningkatan higienitas dari segala aspek. Peningkatan higienitas personal diharapakan dapat meningkatkan kulitas dan keamanan ikan panggang di Loang Baloq sehingga dapat merangsang antusiasme baik konsumen lokal maupun wisatawan domestik dan mancanegara untuk mengunjungi sentra ikan panggang Loang Baloq.

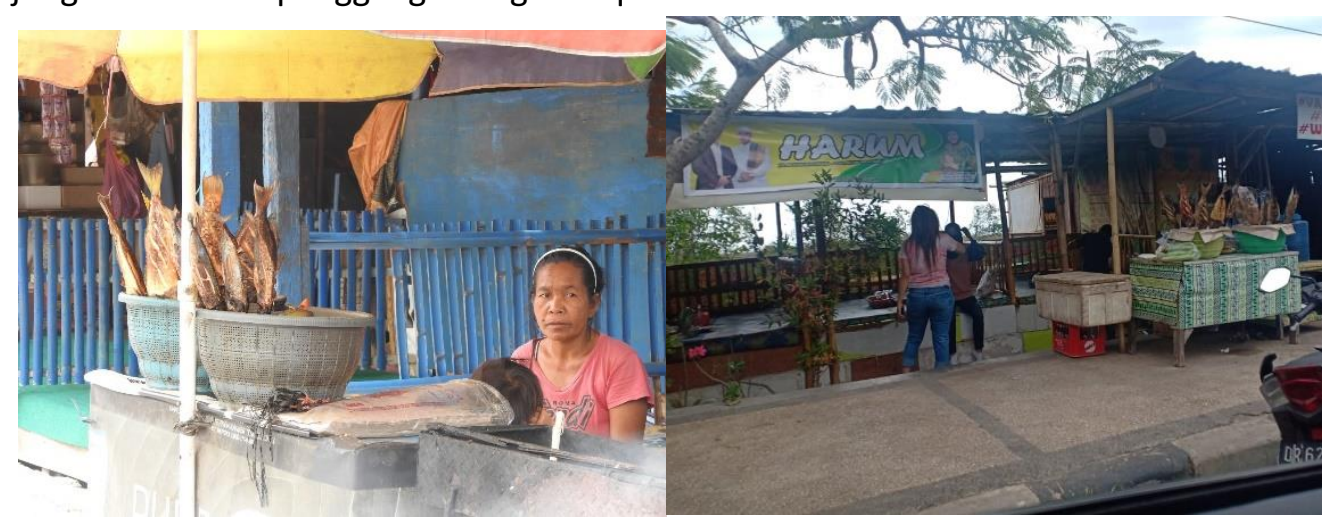

(a)

(b)

Gambar 1. Pedagang Ikan Panggang di Kawasan Loang Baloq (a. Pedagang Tidak Menggunakan Masker, b. Pedagang Tidak Menyediakan Sarana Cuci Tangan yang Memadai)

Kegiatan pengabdian dilaksanakan pada tanggal 8 Oktober 2018 di Kawasan Loang Baloq, Kelurahan Tanjung Karang, Kecamatan Sekarbela, Kota Mataram. Berbeda dengan kegiatan pengabdian pada umumnya yang diksanakan dengan mengumpulkan seluruh peserta terpusat pada suatu lokasi, pelaksanaan kegiatan kali ini dilakukan dengan mengunjungi pedagang ikan panggang pada lapak masing-masing untuk menghindari adanya kerumunan massa sehingga tidak melanggar protokol Covid-19 di era new normal saat ini. Pedagang yang dikunjungi dan mendapatkan sosialisasi 
berjumlah 15 pedagang dari total sekitar 30 lapak. Pedagang yang dipilih untuk mendapatkan sosialisasi saat pelaksanaan kegiatan berdasarkan pada survei yang telah dilakukan sebelumnya dan diprorioritaskan pedagang yang tidak menerapkan personal higiene diantaranya tidak menggunakan masker saat berdagang dan tidak menyediakan sarana cuci tangan yang memadai (Gambar 1).

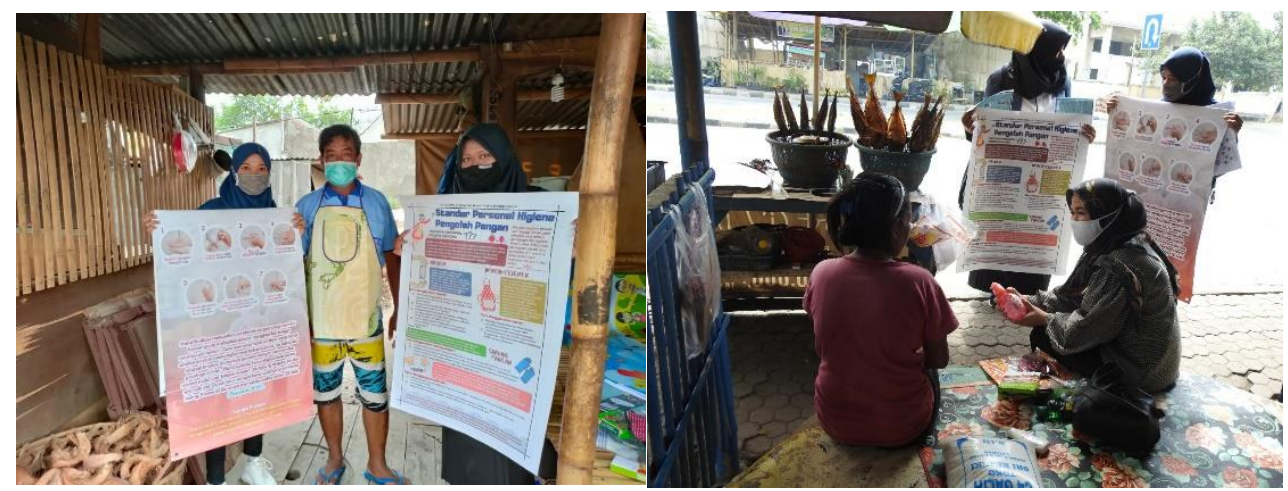

Gambar 2. Penggunaan Poster sebagai Media Penyuluhan

Kegiatan dititikberatkan pada penyuluhan singkat, diskusi dan praktik langsung dalam hal penerapan personal higiene pada proses pengolahan ikan panggang. Kegiatan penyuluhan dilakukan dengan menggunakan bantuan media poster yang terdiri dari poster perlengkapan standar personal higiene serta cara mencuci tangan yang baik dan benar (Gambar 2). Penggunaan poster seebagai media bantu sangat mempemudah proses pemberian penyuluhan penyuluhan karena bisa memberikan gambaran secara langsung mengenai apa yang dibicarakan. Selain itu, untuk meningkatkan pemahaman, dilakukan praktik langsung diantaranya praktik cara menggunakan masker yang benar, cara menggunakan sarung tangan dan apron, serta cara mencuci tangan (Gambar 3). Di akhir kegiatan, tim juga menempelkan stiker terkait personal higiene di lapak pedagang (Gambar 4) atau memberikan leaflet kepada pedagang untuk dapat dipelajari lebih lanjut. Secara keseluruhan kegiatan ini telah berhasil meningkatkan pengetahuan dan motivasi peserta akan pentingnya penerapan personal higiene dalam proses pengolahan ikan panggang. Hal ini dapat dilihat dari kesediaan peserta meluangkan waktu berjualannya untuk mendengarkan penyuluhan dan berdiskusi (Gambar 5) dengan tim pengabdian dan antusiasme peserta dalam menyimak materi dan mengikuti praktik yang diberikan.

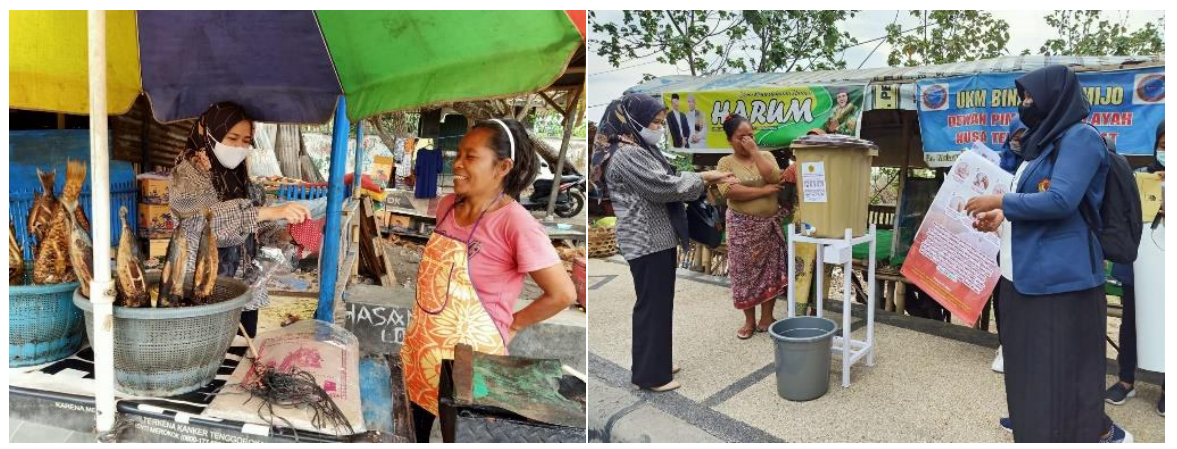

Gambar 3. Praktik a) Cara Menggunakan Masker dan Apron yang Benar dan b) Cara Mencuci Tangan 


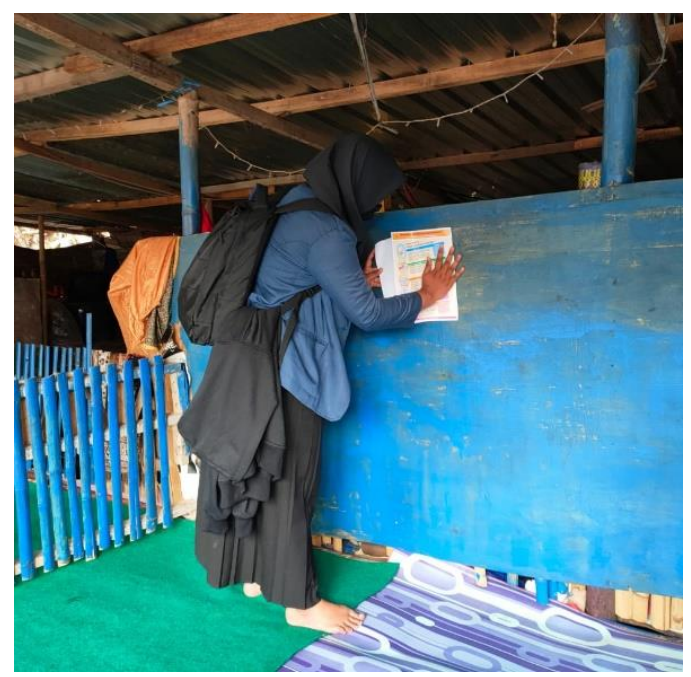

Gambar 4. Penempelan Stiker Prosedur Personal Higiene di Lapak Pedagang

Berdasarkan pada aspek makna dan pentingnya personal higiene dalam pengolahan pangan, pedagang memperoleh pemahaman makna pentingnya personal higiene sebagai syarat mutlak yang menentukan mutu dan keamanan ikan panggang yang dihasilkan. Pedagang yang sebelumnya kurang memiliki kesadaran akan kebersihan diri sebagai pengolah pangan mulai diarahkan untuk mengerti akan makna dan pentingnya personal higiene untuk menghasilkan produk yang berkulitas dan disukai konsumen. Hal ini sesuai dengan perkembang standar mutu yang dipersyaratan konsumen, dimana keamanan pangan merupakan persyaratan utama dan terpenting dari seluruh parameter mutu pangan yang ada. Seperti yang diutarakan oleh Zulfa (2011) bahwa terdapat hubungan antara personal higiene pedagang dan sanitasi makanan dengan keberadaan Eschericia coli pada nasi rames di Pasar Johar Kota Semarang. Keberadaan E. coli mengindikasikan bahwa keamananan pangan sebagai parameter utama mutu pangan tidak terpenuhi. Selain itu, pedagang juga mengetahui resiko jika proses pengolahan ikan panggang tidak sesuai dengan prosedur sanitasi yaitu tidak hanya berdampak terhadap konsumen tetapi juga merugikan mereka sebagai produsen. Bagi konsumen, mengkonsumsi produk dengan kualitas mikrobiologis yang tidak memenuhi standar akibat praktik personal higiene yang buruk pada proses pengolahan dapat mengakibatkan gangguan kesehatan mulai dari mual, muntah, diare dan gejala lainnya. Bagi produsen, hal ini dapat berdampak pada hilangnya kepercayaan konsumen pada produk tersebut hingga penurunan omset penjualan dan yang terburuk adalah pencabutan izin produksi oleh instansi terkait.

Berdasarkan pada aspek perlengkapan standar personal higiene, pedagang juga diperkenalkan dengan berbagai peralatan standar personal higiene beserta fungsinya. Pedagang sebelumnya tidak menggunakan peralatan apapun pada proses pengolahan, bahkan saat pandemi Covid-19 seperti saat ini, para pedagang juga tidak menggunakan masker sehingga tidak memenuhi protocol kesehatan yang berlaku. Padahal, sebagai pedagang yang berinteraksi dengan banyak pembeli seharusnya mereka menggunakan masker sebagai bentuk perlindunag terhadap diri sendiri dan juga konsumen. Oleh karena itu, penyampaian materi terkait peralatan standar sanitasi personal ini juga dilengkapi dengan pemberian beberapa peralatan diantaranya masker, apron dan sarung tangan beserta peragaan cara penggunaan yang benar sehingga manfaat penggunaannya dapat dirasakan. 


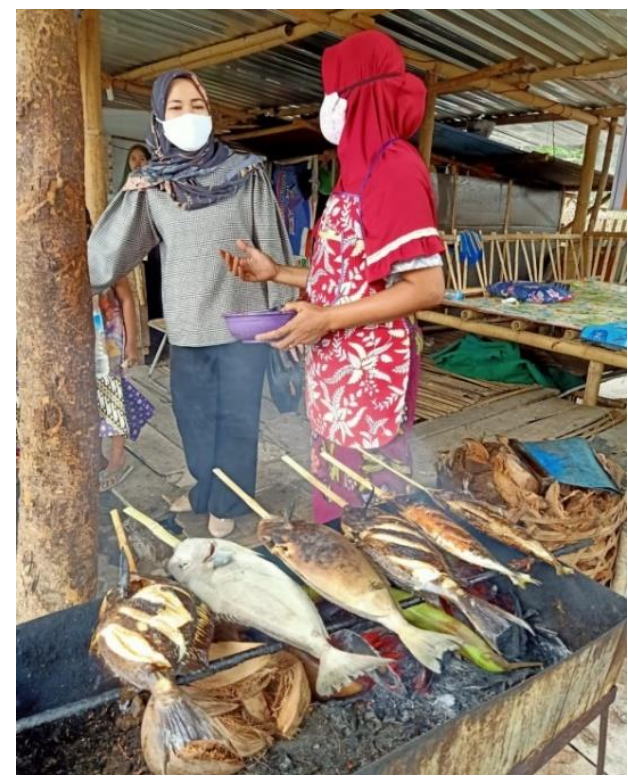

Gambar 5. Diskusi dengan Pedagang Ikan Panggang

Prosedur cuci tangan yang baik dan benar juga sangat penting untuk diterapkan kepada para pedagang ikan panggang karena kondisi tangan yang bersih dapat menjamin kebersihan selama proses pengolahan. Berdasarkan hasil penelitian Chairini (2009) dalam Fadhila dkk. (2015) terdapat hubungan antara perilaku mencuci tangan dengan kualitas bakteriologis (jumlah total mikroba). Dengan demikian mencuci tangan yang baik seharusnya menjadi hal yang wajib dilakukan oleh pedagang sebagai pengolah makanan, akan tetapi hingga saat ini sebagian besar pedagang masih jarang melakukan hal tersebut. Kondisi ini diperburuk oleh faktor kesulitan pedagang saat harus menggunakan sarung tangan sehingga menggunakan sarung tangan cenderung dianggap merepotkan. Oleh karena itu, untuk mengantisipasi hal tersebut maka prosedur cuci tangan yang baik dan benar telah diperagakan dan diikuti oleh peserta penyuluhan.

Pelaksanaan kegiatan pengabdian pada era new normal pandemi Covid-19 ini juga menemui beberapa kendala diantaranya tidak memungkinkan untuk mengumpulkan peserta dalam jumlah banyak di satu tempat dan mayoritas pedagang yang menjadi target kegiatan tidak menggunakan masker. Solusi yang dilakukan untuk menghadapi kendala yang pertama adalah dengan mengubah sistem pelaksanaan dari penyuluhan terhadap kelompok pedagang menjadi penyuluhan secara personal kepada masing-masing pedagang. Solusi yang dilakukan untuk menghadapi kendala kedua adalah dengan menjaga jarak serta membagikan masker dan mengajarkan cara penggunaan masker yang benar sebelum kegiatan diskusi dilaksanakan sehingga kegiatan memenuhi protokol kesehatan yang telah ditentukan.

\section{KESIMPULAN}

Berdasarkan indikator capaian dapat ditarik kesimpulan:

1. Pedagang mulai memahami apa yag dimaksud dengan personal higiene dan pentingnya penerapan personal higiene dalam pengolahan ikan panggang

2. Pedagang telah mengetahui jenis perlengkapan standar personal higiene bagi pengolah pangan beserta cara penggunaannya

3. Pedagang dapat mempraktekkan cara mencuci tangan yang benar. 


\section{UCAPAN TERIMA KASIH}

Penulis mengucapkan terima kasih kepada DIPA PNBP Universitas Mataram yang telah memberi dukungan financial terhadap pengabdian ini.

\section{DAFTAR PUSTAKA}

Ayuningtyas, K., 2019. Kajian Mutu Ikan Panggang Di Jalan Lingkar Selatan Tanjung Karang (Loang Baloq). Skripsi. Fakultas Tekonologi Pangan dan Agroindustri. Universitas Mataram.

Departemen Kesehatan Republik Indonesia., 2004. Higiene Sanitasi Makanan dan Minuman. Jakarta : Ditjen PPM dan PL

Fadhila, M.F., Wahyuningsih, N.E., dan Hanani, D. 2015. Hubungan Higiene Sanitasi dengan Kualitas Bakteriologis pada Alat Makan Pedagang di Wilayah Sekitar Kampus Undip Tembalang. Jurnal Kesehatan Masyarakat. 3 (3): 769-776.

Nugroho, M.S., 2019. Identifikasi Komponen Pendukung Daya Tarik Wisata Loang Baloq Sebagai Wisata Pesisir Di Kota Mataram, Media Bina Ilmiah, Vol.13 No.9 April 2019.

Saksono, L., Isro'in Saksono., 1986. Pengantar Sanitasi. Untuk Keluarga, Industri Makanan dan Industri Pelayanan Makanan. Alumni. Bandung.

Zulfa, N. 2011. Hubungan Higiene Personal Pedagang dan Sanitasi Makanan dengan Keberadaan Eschericia coli pada Nasi Rames di Pasar Johar Kota Semarang Tahun 2011. Skripsi. Jurusan IImu Kesehatan Masyarakat, Fakultas Ilmu Keolahragaan, Universitas Negeri Semarang. 